\title{
Analisis Pengaruh Penjualan Eceran, Pendapatan Sewa Terhadap Laba Komprehensif pada PT. Mitra Adiperkasa, Tbk
}

\author{
Kito Kurniawan ${ }^{1}$ \\ Universitas Buddhi Dharma \\ kitokurniawan@gmail.com
}

\begin{abstract}
Abstrak
Penelitian yang bertujuan mengetahui pengaruh penjualan eceran, dan pendapatan sewa terhadap perolehan laba komprehensif periode keuangan 2008 s/d 2012. Metode penelitian yang digunakan adalah deskriptif kuantitatif pada perusahaan PT. Mitra Adiperkasa, Tbk). Penjualan eceran (X1) berpengaruh signifikan terhadap laba komprehensif (Y). Berdasarkan pengujian nilai $\mathrm{r} 2$ yakni $\mathrm{R}$ square sebesar 0.757 berarti, variabel dependen (Y) dipengaruhi oleh variabel independen (X1) sebesar $75.7 \%$. Pendapatan sewa (X2) tidak berpengaruh signifikan terhadap laba komprehensif (Y). Berdasarkan pengujian nilai r2 yakni R square sebesar 0.204 berarti, variabel dependen (Y) dipengaruhi oleh variabel independen (X2) sebesar 20.4\%. Berdasarkan pengujian koefisien determinasi menghasilkan nilai $\mathrm{r} 2$ yakni $\mathrm{R}$ square sebesar 0.775 berarti, variabel dependen (Y) dipengaruhi oleh variabel independen (X1), (X2) sebesar 77.5\%. Kesimpulan bahwa PT. Mitra Adiperkasa, Tbk terdapat pengaruh signifikan penjualan eceran dan grosir terhadap laba komprehensif periode laporan keuangan.
\end{abstract}

Kata Kunci: Eceran, Pendapatan, Sewa, Laba Komprehensif.

\section{Pendahuluan}

Perkembangan ilmu pengetahuan dewasa ini mendorong peningkatan kebutuhan hidup manusia yang dinamis seiring dengan pemenuhan yang variatif dan kompleks. Pertumbuhan kuantitas kebutuhan seseorang yang beragam disebabkan oleh bergeraknya taraf hidup seseorang kearah positif dalam sudut pandang ekonomi. Kebutuhan hidup sesorang mulai berkembang seiring dengan pertumbuhan ekonomi yang mendorong kemampuan dalam mengelola beragam satuan kebutuhan yang mendasar hingga berujung secara sistemik dalam mengatur kebutuhan dasar (primer), kebutuhan sandang yaitu menengah (secondary), dan kebutuhan pada barang mewah (tertiary/tersier). Peneliti memiliki ketertarikan terhadap penjualan eceran dan grosir, kemudian pendapatan sewa dan jasa pemeliharaan berdasarkan atas pengaruh yang diberikan oleh masingmasing sumber pendapatan tersebut terhadap laba komprehensif.

1. Laporan laba-rugi, yaitu laporan yang menunjukkan hasil usaha dan biaya-biaya selama suatu periode akuntansi.

2. Laporan perubahan ekuitas, yaitu laporan yang menunjukkan sebab-sebab perubahan ekuitas dari jumlah pada awal periode menjadi jumlah ekuitas pada akhir periode.

3. Laporan arus kas, yaitu laporan yang menunjukkan arus kas masuk dan keluar yang dibebankan menjadi arus kas operasi, arus kas investasi dan arus kas pendanaan.

Catatan atas laporan keuangan, yaitu laporan keuangan seperti yang tertera di atas dapat dikatakan sebagai laporan-laporan tujuan umum.

\section{Pendapatan}

Berdasarkan pendapat para ahli yang menjelaskan pengertian dari teori yang dikemukakan di atas, yakni sebagai berikut:

${ }^{1}$ Korespondensi: Kito Kurniawan. Universitas Buddhi Dharma. Jl. Imam Bonjol No. 41 Karawaci Ilir-Tangerang. kitokurniawan@gmail.com 
1. Pengertian pendapatan bersih adalah hasil dari pendapatan bruto yang dikurangi atas retur penjualan dan diskon penjualan pada suatu periode laporan laba rugi. (Munawir, 2007)

2. Pengertian Pendapatan Sewa, yakni berdasakan Surat Edaran tentang Pengertian Sewa Dan Penghasilan Lain Sehubungan Dengan Penggunaan Harta, Jasa Teknik, Jasa Manajemen, Dan Jasa Konsultan Sebagaimana Dimaksud Dalam Pasal 23 Ayat (1) Huruf c UndangUndang Nomor 36 Tahun 2008. (Direktur Jenderal Pajak, 2010)

\section{Pengertian Penjualan}

Usaha eceran (retailing) meliputi semua kegiatan yang terlibat dalam penjualan barang atau jasa secara langsung ke konsumen akhir untuk penggunaan pribadi dan bukan bisnis. Pengecer atau toko eceran adalah usaha bisnis yang volume penjualannya terutama berasal dari penjualan eceran. (Teguh \& Rusli)

\section{Laba Komprehensif}

Pengertian Laba Komprehensif :

1. Pengertian jumlah laba komprehensif dalam pelaporan laba rugi pelaporan yang dipergunakan untuk menyajikan secara total keseluruhan komponen dalam pelaporan ekuitas. Pelaporan ini digunakan untuk melaporkan item - item seperti pendapatan, biaya, keuntungan ataupun kerugian yang secara tersendiri dalam prinsip akuntansi berterima umum dimasukan dalam jenis pelaporan pos laba komprehensif tetapi dalam penyajian dipihak lain tidak termasuk dalam pos pelaporan net income. Pos laba komprehensif merupakan item yang secara tersendiri langsung ditandingkan dalam laporan perubahan modal tanpa melalui penandingan. (Financial Accounting Standart Board, 2010)

2. Pengertian laba atau keuntungan adalah nilai penerimaan total perusahaan dikurangi biaya total yang dikeluarkan perusahaan. (Raharja, 2004)

3. Laba rugi adalah total penghasilan dikurangi beban, kemudian termasuk komponen-komponen penghasilan komprehensif lain pada laba rugi komprehensif mencakup semua komponen laba atau rugi yang berkaitan dengan penghasilan dan penghasilan komprehensif lain. (Surya, 2012)

\section{Kerangka Berpikir}

Dalam pengajuan tesis ini Peneliti melalui data Empiris Sekunder Kepustakaan berbagai proses mulai tahap penetapan perusahaan yang akan diteliti, menganalisa kinerja laporan keuangan, mengidentifikasi kebijakan akuntansi yang diterapkan perusahaan, mengobservasi hasil laporan keuangan yang telah diaudit oleh Kantor Akuntan Publik (KAP) selanjutnya menganalisa kebijakan terhadap penjualan eceran dan grosir, pendapatan sewa dan jasa pemeliharaan (Yanti \& Oktari, Konversi Faktor Penerimaan Audit Teknologi oleh Kantor Akuntan Publik di Indonesia Menggunakan Kerangka Kerja I-TOE, 2018) .

\section{Hipotesis}

Hipotesis adalah hal yang dianggap benar sebagai alasan atas pendapat walaupun kebenarannya masih harus dapat dibuktikan, dengan kata lain Hipotesis adalah anggapan atau pendapat sementara. (Sieh, 2011)

Ho: Diduga Penjualan Eceran dan Grosir tidak berpengaruh terhadap Laba Komprehensif

H1: Diduga Penjualan Eceran dan Grosir berpengaruh terhadap Laba Komprehensif

Ho: Diduga Pendapatan Sewa dan Jasa Pemeliharaan tidak berpengaruh terhadap Laba Komprehensif

H2: Diduga Pendapatan Sewa dan Jasa Pemeliharaan berpengaruh terhadap Laba Komprehensif 
Ho: Diduga Penjualan Eceran dan Grosir, Pendapatan Sewa dan Jasa Pemeliharaan secara simultan tidak berpengaruh terhadap Laba Komprehensif

H3: Diduga Penjualan Eceran dan Grosir, Pendapatan Sewa dan Jasa Pemeliharaan secara simultan berpengaruh terhadap Laba Komprehensif

\section{Metodologi Penelitian \\ Populasi}

Populasi dari penelitian ini adalah laporan laba rugi komprehensif konsolidasian (consolidated statements of comprehensive income) pada perusahaan industri retail di Indonesia.

\section{Sampel}

Pengertian sampel adalah bagian dari populasi yang dipilih dengan sampling tertentu untuk bisa mewakili populasi. (Pariani, 2012)

Berdasarkan pengertian sampel di atas maka yang menjadi sampel dalam penelitian ini adalah laporan laba rugi komprehensif kurun waktu 5 tahun periode laporan keuangan 2008 - 2012 PT. Mitra Adiperkasa, Tbk.

\section{Variabel Penelitian}

Identifikasi variabel perlu dilakukan untuk memberikan gambaran dan acuan dalam penelitian. Berdasarkan rumusan masalah dan hipotesis yang diajukan, variabel-variabel dalam penelitian ini dapat diidentifikasikan sebagai berikut :

\section{Variabel bebas}

Variabel bebas atau variabel penyebab (independent variabels) adalah variabel yang menyebabkan atau mempengaruhi, yaitu faktor - faktor yang dikukur, dimanipulasi atau dipilih oleh peneliti untuk menentukan hubungan antara fenomena yang diobservasi atau diamati. Variabel-variabel bebas dalam model jalur ialah semua variabel yang tidal ada penyebab eksplisitnya atau dalam diagram tidak ada anak-anak panah menuju kerahnya, selain pada bagian kesalahan pengukuran (Efendi, 1989)

Pada penelitian ini variabel bebas adalah :

a. Penjualan eceran dan grosir (X1)

b. Pendapatan Sewa dan Jasa Pemeliharaan (X2)

\section{Variabel Terikat}

Variabel terikat atau variabel tergantung (dependent variables) adalah faktor - faktor yang diobservasi dan diukur untuk menentukan adanya pengaruh variabel bebas, yaitu faktor yang muncul, atau tidak muncul, atau berubah sesuai dengan yang diperkenalkan oleh peneliti. Dalam analisa jalur variabel terikat adalah variabel yang mempunyai anak panah menuju ke arah variabel tersebut. Variabel yang mencakup didalamnya adalah variabel perantara dan variabel tergantung/terikat. (Efendi, 1989)

Dalam penelitian ini variabel terikat adalah :

Laba Komprehensif

Definisi Operasional Variabel

Pada penelitian ini, operasional variabel yang didefinisikan sebagai berikut :

a. Penjualan Eceran dan Grosir (X1)

b. Pendapatan Sewa dan Jasa Pemeliharaan (X2)

c. Laba Komprehensif (Y)

Rancangan Analisis

Pada penelitian ini dilakukan suatu analisa pengaruh variabel bebas (independent variable) terhadap variabel terikat (dependent variable) dengan menggunakan pengujian asumsi klasik. 


\section{Uji Hipotesis}

Pada penelitian ini dilakukan suatu uji hipotesis atas variabel bebas (independent variable) yang diduga berpengaruh terhadap variabel terikat (dependent variable).

\section{Uji Signifikansi Parameter Individual/Uji Statistik t (Uji Parsial)}

Kriteria pengambilan keputusannya adalah sebagai berikut :

a. Apabila t hitung $>t$ tabel, berarti secara parsial variabel independen berpengaruh signifikan terhadap variabel dependen.

b. Apabila $\mathrm{t}$ hitung $<\mathrm{t}$ tabel, berarti secara parsial variabel independen tidak berpengaruh signifikan terhadap variabel dependen. (Nathalia, 2013)

\section{Uji Signifikansi Simultan/Uji Statistik F}

Kriteria pengambilan keputusannya adalah sebagai berikut :

a. Apabila $F$ hitung $>F$ tabel dan tingkat signifikansi $(a)<0,05$ maka semua variabel independen secara bersama-sama berpengaruh signifikan terhadap variabel dependen.

b. Apabila $F$ hitung $<F$ tabel dan tingkat signifikansi (a) $>0,05$ maka semua variabel independen secara bersama-sama tidak berpengaruh signifikan terhadap variabel dependen.

Berdasarkan hasil pengujian yang menggunakan SPSS v20 terdapat pengaruh signifikan penjualan eceran dan grosir terhadap laba komprehensif periode laporan keuangan

\section{Hasil}

PT. Mitra Adiperkasa, Tbk merupakan perusahaan ritel yang menaungi beberapa merek dagang terkenal di Indonesia. Berdasarkan atas objek penelitian yaitu laporan laba rugi studi kasus pada PT. Mitra Adiperkasa, Tbk kurun waktu 5 tahun periode laporan keuangan yang telah diaudit oleh kantor akuntan publik, maka variabel penelitian tersebut adalah sebagai berikut :

1. Variabel Bebas (Independent Variable)

a. Penjualan Eceran dan Grosir (X1)

b. Pendapatan Sewa dan Jasa Pemeliharaan (X2)

2. Variabel Terikat (Dependent Variable)

Laba Komprehensif (Y)

\section{Analisis Deskriptif Data Penelitian}

Analisis deskriptif digunakan untuk memberikan gambaran variabel yang akan dijadikan sampel dengan cara menyajikan data kuantitatif. (Nathalia, 2013)

Berikut adalah tabel variabel penelitian yang dikemukakan dalam kurun waktu 5 tahun, seperti di bawah ini :

Tabel 1. Variabel Penelitian

\begin{tabular}{|c|c|c|c|c|c|c|}
\hline \multirow{2}{*}{ Tahun } & \multicolumn{7}{|c|}{ Pendapatan (Dalam Ribuan Rupiah) } \\
\cline { 2 - 7 } & \multicolumn{2}{|c|}{$\begin{array}{c}\text { Penjualan Eceran dan } \\
\text { Grosir (X1) }\end{array}$} & \multicolumn{2}{c|}{$\begin{array}{c}\text { Pendapatan Sewa dan } \\
\text { Jasa Pemeliharaan (X2) }\end{array}$} & \multicolumn{2}{c|}{ Laba Komprehensif (Y) } \\
\cline { 2 - 7 } & Nilai & $\begin{array}{c}\text { Tingkat } \\
\text { Kenaikk } \\
\text { an (\%) }\end{array}$ & Nilai & $\begin{array}{c}\text { Tingkat } \\
\text { Kenaikkan } \\
(\%)\end{array}$ & Nilai & $\begin{array}{c}\text { Tingkat } \\
\text { Kenaikkan } \\
(\%)\end{array}$ \\
\hline 2008 & 2.853 .956 .784 & $41,70 \%$ & 45.264 .000 & $10.787,39 \%$ & -69.790 .974 & $-191,49 \%$ \\
\hline 2009 & 3.452 .417 .729 & $71,41 \%$ & 52.622 .744 & $12.557,40 \%$ & 163.986 .260 & $114,97 \%$ \\
\hline 2010 & 3.983 .644 .889 & $97,79 \%$ & 53.358 .932 & $12.734,47 \%$ & 201.071 .471 & $163,58 \%$ \\
\hline
\end{tabular}




\begin{tabular}{|l|l|l|l|l|l|l|}
\hline 2011 & 5.036 .906 .424 & $150,08 \%$ & 51.759 .196 & $12.349,69 \%$ & 358.190 .758 & $369,55 \%$ \\
\hline 2012 & 6.631 .209 .473 & $229,24 \%$ & 55.523 .486 & $13.255,11 \%$ & 436.641 .660 & $472,39 \%$ \\
\hline
\end{tabular}

(Sumber : Diolah dari Laporan Keuangan PT. MAP, Tbk periode 2008-2012)

1. Penjualan Eceran dan Grosir (X1) memiliki prosentase kenaikkan sebesar 229,24\% dari tahun dasar

2. Pendapatan Sewa dan Jasa Pemeliharaan (X2) memiliki prosentase kenaikkan sebesar $13.255,11 \%$ dari tahun dasar

3. Laba Komprehensif (Y) memiliki prosentase kenaikkan sebesar 472,39\% dari tahun dasar

\section{Uji Kualitas Data dengan Uji Asumsi Klasik}

Berdasarkan data yang telah diperoleh dan dianalisis, maka diperlukan pengujian lebih lanjut, sebagai berikut :

\section{Uji Validitas}

Tabel 2. Uji validitas

\begin{tabular}{|l|c|c|}
\hline \multicolumn{3}{|c|}{ Item-Total Statistics } \\
\hline & $\begin{array}{l}\text { Corrected Item-Total } \\
\text { Correlation }\end{array}$ & $\begin{array}{l}\text { Cronbach's Alpha if } \\
\text { Item Deleted }\end{array}$ \\
\hline Penjualan Eceran dan Grosir & .971 & .641 \\
\hline Pendapatan Sewa dan Jasa Pemeliharaan & .723 & .746 \\
\hline Laba Komprehensif & .836 & .750 \\
\hline
\end{tabular}

Berdasarkan hasil pengujian di atas maka diperoleh, kesimpulan sebagai berikut :

a. Variabel Independen :

1) Penjualan eceran dan grosir (X1) berdasarkan nilai Corrected Item-Total Correlation lebih besar dari syarat Corrected Item-Total Correlation, yakni 0.971>0.240, sehingga dapat disimpulkan valid.

2) Pendapatan sewa dan jasa pemeliharaan (X2) berdasarkan nilai Corrected Item-Total Correlation lebih besar dari syarat Corrected Item-Total Correlation, yakni $0.723>0.240$, sehingga dapat disimpulkan valid.

b. Variabel Dependen

Laba komprehensif (Y) berdasarkan nilai Corrected Item-Total Correlation lebih besar dari syarat Corrected Item-Total Correlation, yakni 0.836>0.240, sehingga dapat disimpulkan valid.

\section{Uji Reabilitas}

Tabel 3. Reliability Statistics

\begin{tabular}{|c|c|}
\hline Cronbach's Alpha & N of Items \\
\hline .741 & 10 \\
\hline
\end{tabular}

Berdasarkan hasil uji di atas menunjukkan bahwa secara simultan variabel independen lebih besar dari 0,6 yang mendekati nilai 0,8, berarti hasil tersebut telah reliabel. Kemudian pada hasil analisis menggunakan SPSS pada tabel Item-Total Statistics, maka nilai setiap butir pernyataan yang terletak pada kolom 'Cronbach's Alpha if Item Deleted' dengan nilai lebih besar dari 0,6 yang mendekati nilai 0,8 secara simultan dapat dikatakan sudah reliable. 


\section{Uji Autokorelasi}

Tabel 4. Uji Autokorelasi

Model Summary ${ }^{\circ}$

\begin{tabular}{|l|r|r|r|r|l|}
\hline Model & \multicolumn{1}{|c|}{$\mathrm{R}$} & R Square & $\begin{array}{c}\text { Adjusted R } \\
\text { Square }\end{array}$ & $\begin{array}{c}\text { Std. Error of the } \\
\text { Estimate }\end{array}$ & Durbin-Watson \\
\hline 1 & $.881^{\mathrm{a}}$ & .775 & .711 & 76969409474.97853 & 2.955 \\
\hline
\end{tabular}

a. Predictors: (Constant), X2, X1

b. Dependent Variable: $Y$

(Sumber Data diolah menggunakan SPSS versi 20 Durbin-Watson Anaiysis )

Berdasarkan pada hasil uji autokorelasi diperoleh nilai uji Durbin-Watson yaitu 2,955 yang berarti nilai tersebut berada dalam kategori.

\section{Uji Normalitas}

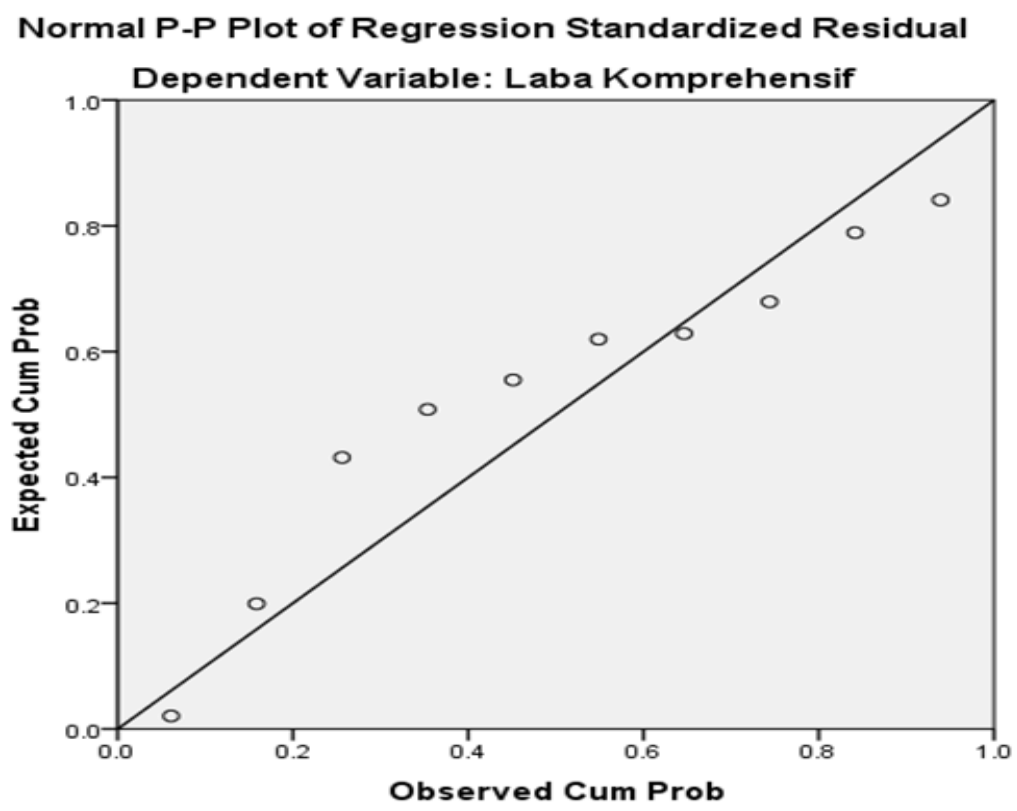

Gambar 1.

Berdasarkan gambar di atas, dapat diketahui bahwa titik-titik sebaran data menyebar di sekitar garis diagonal dan mengikuti arah garis diagonal, maka model regresi memenuhi asumsi normalitas.

\section{Uji Homogenitas}

Tabel 5. Test of Homogeneity of Variances

Test of Homogeneity of Variances

Laba komprehensif

Laba komprehensif
\begin{tabular}{|c|c|c|c|}
\hline Levene Statistic & $\mathrm{df} 1$ & $\mathrm{df} 2$ & Sig. \\
\hline 12.654 & 1 & 18 & .002 \\
\hline
\end{tabular}


Berdasarkan uji homogenitas dengan menggunakan (test of homogeneity of variances) maka diperoleh nilai Sig. sebesar 0,02, yang berarti Fhitung $\leq$ Ftabel, yaitu $0,02 \leq 0,05$, maka H0 diterima (homogen), berarti antara variabel independen bersifat homogen.

\section{Uji Multikolinearitas}

Tabel 6. Hasil Uji Multikolinearitas Coefficients $^{\mathrm{a}}$

\begin{tabular}{|c|c|c|c|c|c|c|c|}
\hline \multirow[t]{2}{*}{ Model } & \multicolumn{2}{|c|}{ Unstandardized Coefficients } & \multirow{2}{*}{$\begin{array}{c}\begin{array}{c}\text { Standardized } \\
\text { Coefficients }\end{array} \\
\text { Beta }\end{array}$} & \multirow[t]{2}{*}{$t$} & \multirow[t]{2}{*}{ Sig. } & \multicolumn{2}{|c|}{$\begin{array}{l}\text { Collinearity } \\
\text { Statistics }\end{array}$} \\
\hline & B & Std. Error & & & & $\begin{array}{c}\text { Toleranc } \\
\mathrm{e}\end{array}$ & VIF \\
\hline (Constant) & $\begin{array}{r}145902258543.3 \\
31\end{array}$ & $\begin{array}{r}67579775298.8 \\
98\end{array}$ & & 2.159 & $\begin{array}{r}.06 \\
8\end{array}$ & & \\
\hline $\begin{array}{l}\text { Penjualan Eceran dan } \\
\text { Grosir }\end{array}$ & .099 & .023 & .984 & 4.219 & $\begin{array}{r}.00 \\
4\end{array}$ & .590 & 1.694 \\
\hline $\begin{array}{l}\text { Pendapatan Sewa dan } \\
\text { Jasa Pemeliharaan }\end{array}$ & -1.079 & 1.416 & -.178 & -.762 & $\begin{array}{r}.47 \\
1\end{array}$ & .590 & 1.694 \\
\hline
\end{tabular}

a. Dependent Variable: Laba Komprehensif

Ketentuan pengambilan keputusan dalam uji Multikolinearitas, sebagai berikut :

a. Jika tolerance value $>0,10$ dan $\mathrm{VIF}<10$, maka tidak terjadi multikolinearitas.

b. Jika tolerance value $<0,10$ dan $\mathrm{VIF}>10$, maka terjadi multikolinearitas.

Berdasarkan pengujian di atas diperoleh, hasil uji multikolinearitas masing-masing variabel independen yaitu, penjualan eceran dan grosir (X1) nilai toleransi lebih besar terhadap syarat tolerance, yakni 0.59>0.1, kemudian nilai VIF lebih kecil terhadap syarat VIF, yakni $1.694<10$. Pendapatan sewa dan jasa pemeliharaan (X2) nilai tolerance lebih besar terhadap syarat tolerance, yakni 0.59>0.1, kemudian nilai VIF lebih kecil terhadap syarat VIF, yakni $1.694<10$. Maka diperoleh nilai tolerance lebih besar terhadap syarat tolerance dan nilai VIF lebih kecil terhadap syarat VIF. Hasil tersebut menunjukkan bahwa tidak terjadi multi kolinearitas.

\section{Uji Heterokedastisitas}

Tabel 7. Uji Spearman's Rho Correlations

\begin{tabular}{|c|c|c|c|c|}
\hline & & & $\begin{array}{c}\text { Penjualan } \\
\text { Eceran dan } \\
\text { Grosir } \\
\end{array}$ & \begin{tabular}{|c} 
Pendapatan \\
Sewa dan Jasa \\
Pemeliharaan
\end{tabular} \\
\hline $\begin{array}{l}\text { Spearman's } \\
\text { rho }\end{array}$ & $\begin{array}{l}\text { Penjualan Eceran dan Grosir } \\
\text { Pendapatan Sewa dan Jasa } \\
\text { Pemeliharaan }\end{array}$ & $\begin{array}{l}\text { Correlation } \\
\text { Coefficient } \\
\text { Sig. (2-tailed) } \\
\mathrm{N} \\
\text { Correlation } \\
\text { Coefficient } \\
\text { Sig. (2-tailed) } \\
\mathrm{N}\end{array}$ & $\begin{array}{l}1.000 \\
10 \\
.867^{*} \\
.001 \\
10\end{array}$ & $\begin{array}{r}.867^{\star *} \\
.001 \\
10 \\
1.000 \\
.001 \\
10\end{array}$ \\
\hline
\end{tabular}

Berdasarkan pengujian di atas diperoleh, hasil uji spearman's rho, penjualan eceran dan grosir (X1) nilai Sig.(2-tailed) lebih kecil terhadap syarat nilai Sig.(2-tailed, yakni $0.001<0.05$. Pendapatan sewa dan jasa pemeliharaan (X2) nilai Sig.(2-tailed) lebih kecil terhadap syarat nilai Sig. (2-tailed), yakni $0.001<0.05$. Maka diperoleh semua variabel independen mempunyai signifikansi korelasi kurang dari 0,05 dengan nilai Sig.(2-tailed), yakni 0,001<0,05. Hasil ini menunjukkan bahwa model regresi ini terdapat ketidaksamaan variance dari residual satu pengamatan ke pengamatan yang lain. 


\section{Koefisien Determinasi}

\begin{tabular}{|c|c|c|c|c|}
\hline Model & $\mathrm{R}$ & R Square & $\begin{array}{l}\text { Adjusted R } \\
\text { Square }\end{array}$ & $\begin{array}{l}\text { Durbin- } \\
\text { Watson }\end{array}$ \\
\hline 1 & $.881^{a}$ & .775 & .711 & 2.955 \\
\hline
\end{tabular}

Berdasarkan pengujian yang telah dilakukan menghasilkan nilai $\mathrm{r} 2$ yakni $\mathrm{R}$ square sebesar 0.775 dikonversikan dalam persentase, maka $0.775 \times 100 \%=77.5 \%$ berarti, variabel dependen (terikat) dipengaruhi oleh variabel independen (bebas) sebesar 77.5\%.

Nilai ini berarti bahwa sebesar $77.5 \%$ laba komprehensif dipengaruhi oleh penjualan eceran dan grosir, dan pendapatan sewa dan jasa pemeliharaan.

Sedangkan sisanya, yakni sebesar $22.5 \%$ dapat dijelaskan oleh faktor-faktor lainnya diluar model regresi ini.

\section{Uji Hipotesis}

Berdasarkan uji hipotesis yang dikemukakan dalam pengujian, yakni sebagai berikut :

\section{Uji Statistik t (Uji Parsial)}

Tabel 9. Hasil Uji t X1 \& X2 terhadap Y

Coefficients $^{\mathrm{a}}$

\begin{tabular}{|c|c|c|c|c|c|}
\hline \multirow[t]{2}{*}{ Model } & \multicolumn{2}{|c|}{ Unstandardized Coefficients } & \multirow{2}{*}{$\begin{array}{c}\text { Standardized } \\
\text { Coefficients } \\
\text { Beta } \\
\end{array}$} & \multirow[t]{2}{*}{$\mathrm{T}$} & \multirow[t]{2}{*}{ Sig. } \\
\hline & B & Std. Error & & & \\
\hline (Constant) & $\begin{array}{r}14590225 \\
8543.331\end{array}$ & $\begin{array}{r}67579775298.8 \\
98\end{array}$ & & -2.159 & .068 \\
\hline${ }^{1}$ Penjualan Eceran dan Grosir & .099 & .023 & .984 & 4.219 & .004 \\
\hline $\begin{array}{l}\text { Pendapatan Sewa dan Jasa } \\
\text { Pemeliharaan }\end{array}$ & -1.079 & 1.416 & -.178 & -.762 & .471 \\
\hline
\end{tabular}

a. Dependent Variable: Laba Komprehensif

(Sumber : Data diolah menggunakan SPSS versi 20 Regression Linear Analysis)

Uji Statistik t ,Nilai t tabel pada DF2 (penyebut)=7, yaitu t tabel sebesar 2,364, kemudian berdasarkan hasil uji di atas, diperoleh nilai t hitung pada masing-masing variabel independen yaitu, penjualan eceran dan grosir (X1) nilai t hitung lebih besar terhadap $t$ tabel, yakni 4.219>2.364, sehingga dapat diketahui bahwa terjadi koefisien variabel independen signifikan. Sedangkan pendapatan sewa dan jasa pemeliharaan (X2) nilai t hitung lebih kecil terhadap $\mathrm{t}$ tabel, yakni $-0.762<2.364$, sehingga dapat diketahui bahwa koefisien variabel independen tidak signifikan. 


\section{Uji Signifikansi Simultan/Uji Statistik F}

Tabel 10. Hasil Uji ANOVA X1 \& X2 terhadap Y

ANOVA $^{\mathrm{a}}$

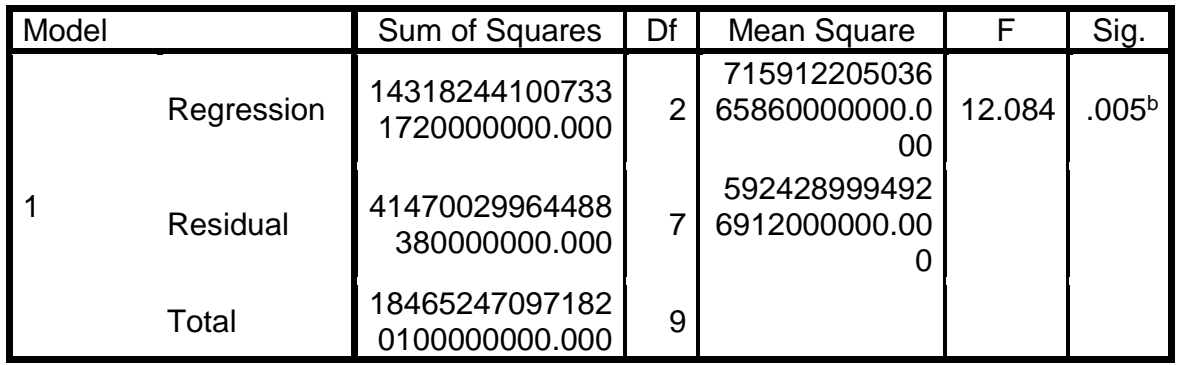

a. Dependent Variable: Laba Komprehensif

b. Predictors: (Constant), Pendapatan Sewa dan Jasa Pemeliharaan, Penjualan Eceran dan Grosir

Uji statistik $\mathrm{F}$ bertujuan untuk menguji secara signifikansi pengaruh variabel independen terhadap variabel dependen secara bersama-sama dengan melihat nilai signifikansi $\mathrm{F}$. (Nathalia, Uji Statistik F, 2013)

Berdasarkan uji ANOVA di atas, menghasilkan $\mathrm{F}$ hitung sebesar 12,084 dengan tingkat signifikansi 0,005. Nilai $\mathrm{f}$ tabel dapat diketahui dengan $\mathrm{DF}$ (pembilang) $=2$ dan $\mathrm{DF} 2$ (penyebut)=7, sehingga diperoleh nilai $\mathrm{F}$ tabel sebesar 4,740. Maka kesimpulan yang dapat diambil atas pengujian tersebut adalah nilai $\mathrm{F}$ hitung $>\mathrm{F}$ tabel, yakni 12,084>4,740 dengan tingkat signifikansi $0,005<0,05$, sehingga semua variabel independen, yaitu penjualan eceran dan grosir (X1) dan pendapatan sewa dan jasa pemeliharaan (X2) secara bersama-sama berpengaruh signifikan terhadap laba komprehensif (Y)

\section{Kesimpulan}

Berdasarkan pada hasil penelitian dan pembahasan, maka dapat diambil suatu kesimpulan sebagai berikut :

1. Penjualan eceran dan grosir (X1) berpengaruh signifikan terhadap laba komprehensif (Y). Hal dapat ini dijelaskan berdasarkan pengujian yang telah dilakukan menghasilkan nilai $\mathrm{r} 2$ yakni $\mathrm{R}$ square sebesar 0.757 berarti, variabel dependen (terikat) laba komprehensif (Y) dipengaruhi oleh variabel independen (bebas) penjualan eceran dan grosir (X1) sebesar 75.7\%. Kemudian berdasarkan pada pengujian hipotesis dengan uji $\mathrm{t}$ diperoleh nilai $\mathrm{t}$ hitung $>\mathrm{t}$ tabel, dan uji $\mathrm{F}$ diperoleh F hitung $>\mathrm{F}$ tabel, yakni 24,892>4,740 dengan tingkat signifikansi 0,001 <0,05.

2. Pendapatan sewa dan jasa pemeliharaan (X2) tidak berpengaruh signifikan terhadap laba komprehensif (Y). Hal ini dapat dijelaskan berdasarkan pengujian yang telah dilakukan menghasilkan nilai $\mathrm{r} 2$ yakni $\mathrm{R}$ square sebesar 0.204 berarti, variabel dependen (terikat) laba komprehensif (Y) dipengaruhi oleh variabel independen (bebas) pendapatan sewa dan jasa pemeliharaan (X2) sebesar 20.4\%. Kemudian berdasarkan pada pengujian hipotesis dengan uji $\mathrm{t}$ diperoleh nilai t hitung $<\mathrm{t}$ tabel, yakni $1,433<2,364$, dan uji $\mathrm{F}$ diperoleh nilai $\mathrm{F}$ hitung $<\mathrm{F}$ tabel, yakni $2,053<4,740$ dengan tingkat signifikansi 0,190>0,05.

3. Penjualan eceran dan grosir (X1), dan pendapatan sewa dan jasa pemeliharaan (X2) secara silmultan berpengaruh terhadap laba komprehensif (Y). Hal ini dapat dijelaskan berdasarkan pengujian yang telah dilakukan menghasilkan nilai r2 yakni R square sebesar 0.775 berarti, variabel dependen (terikat) laba komprehensif (Y) dipengaruhi oleh variabel independen (bebas) penjualan eceran dan grosir (X1), dan pendapatan sewa dan jasa pemeliharaan (X2) sebesar $77.5 \%$. Kemudian berdasarkan pengujian nilai $t$ hitung $>t$ tabel dan nilai $F$ hitung $>\mathrm{F}$ 
tabel, yakni 12,084>4,740 dengan tingkat signifikansi $0,005<0,05$, sehingga semua variabel independen, yaitu penjualan eceran dan grosir (X1) dan pendapatan sewa dan jasa pemeliharaan (X2) secara bersama berpengaruh signifikan terhadap laba komprehensif

\section{Daftar Pustaka}

Direktur Jenderal Pajak. (2010). Pengertian Pendapatan Sewa. Surat Edaran Tentang Pengertian Pendapatan Sewa dan Penghasilan Lain, 23.

Efendi, S. (1989). Pengertian Variabel Bebas. Pengantar Statistik, 36.

Financial Accounting Standart Board. (2010). Pengertian Jumlah Laba Komprehensif. Statement of Financial Accounting Conceps, 130.

Munawir, D. (2007). Pengertian Pendapatan Bersih. PengantarAkuntansi, 1.

Nathalia, M. (2013). Analisis Deskriptif. Analisa Statistika, 56.

Pariani. (2012). Pengertian Sampel. Pengantar Statistik, 31.

Raharja. (2004). Pengertian Laba Komprehensif. Pengantar Akuntansi, 21.

Sieh, L. (2011). Pengertian Hipotesis. Analisa Laporan keuangan, 25.

Surya. (2012). Laba rugi. Pengantar Akuntansi, 24.

Teguh, H., \& Rusli, A. R. (1997). Usaha Eceran . Pengantar AKuntansi, 18.

Yanti, L. D., \& Hartono, L. (2019). Effect of Leverage, Profitability and Company Size on Tax Aggressiveness. (Empirical Study: Subsector Manufacturing Companies Food, Beverage, Cosmetics and Household Purposes Manufacturing Listed on the Indonesia Stock Exchange for 2014-2017). eCo-Fin, 1(1), 1-11. doi:https://doi.org/10.32877/ef.v1i1.52

Yanti, L. D., \& Oktari, Y. (2018). Konversi Faktor Penerimaan Audit Teknologi oleh Kantor Akuntan Publik di Indonesia Menggunakan Kerangka Kerja I-TOE. eCo-Buss, 1(1), 1-6. doi:https://doi.org/10.32877/eb.v1i1.10 